\title{
Rethinking Quality Assurance in Curriculum Development and Implementation for Higher Education in Africa
}

\author{
Innocent Mutale Mulenga, PhD \\ The University of Zambia
}

\section{Corresponding Author: innocent.mulenga@unza.zm}

\begin{abstract}
Far-reaching advances and change in technology, climate and global economic integration are transforming the way we live today in ways that we do not yet fully understand. In sub-Saharan Africa, these uncertainties make a dramatic increase in population and a rapid expansion and demand in higher education. This creates challenges especially where higher education curriculum development and quality assurance are concerned since higher education has to provide the much needed appropriate work force. In this paper, the author explores the opportunities that quality assurance in higher education curriculum development can ride on using the thinking behind $21^{\text {st }}$ century competencies. The chronicle of this discussion combines clear academic definitions of curriculum, curriculum development and then an analysis of how $21^{\text {st }}$ century competencies may bench mark quality assurance in curriculum development for higher education. The final section of the paper brings together some challenges that are real threats and impediments to quality assurance in curriculum development in most African tertiary institutions. In the conclusion, the author feels that there are no reasons why African countries cannot transform challenges into stepping stones through quality assurance and improvement of their higher education sector so as to make it vibrant and productive. This will require a mind-set transformation.
\end{abstract}

Key words: Higher Education, Curriculum Development, Quality Assurance, $21^{\text {st }}$ Century Skills, Competencies.

\section{Introduction}

In almost all parts of the world, graduates from higher education or tertiary institutions directly take up positions of responsibility and decision making that influence economies of their nations. Given the underdevelopment of most countries in Africa, the demand for relevant higher education cannot be overemphasised. On the other hand, however, African institutions of higher learning have been faced with many challenges arising from increased student enrolment, liberalization of education systems, poor funding, brain drain of its academic staff and the need to catch up with modern technology as elaborated by scholars such as Teferra and Altbach (2004), Materu (2007), Mohamedbhai (2011), Goujon, Haller and Kmet (2017), Masaiti and Simuyaba (2018). As a result of all these pressures, higher education is challenged to maintain quality in curriculum development and implementation. Thus to ensure that education programmes in these institutions meet local and international standards, quality assurance is a driver for institutions to achieve excellence if the graduates have to remain relevant to their societies. Moreover, curriculum development for higher education sits at the intersection of the national and the university or college policy, educational research and academic practice, which in most cases may create a complicated literature. For instance, institutional policy can be challenging and sometimes an impediment to quality education because of the traditional cultures of university education. Although university traditions tend to take long to change, when it comes to curriculum development, it is vital to move with the changing times or else institutions may risk offering outdated and irrelevant programmes.

Unlike other lower levels of education, academicians in universities usually find themselves 
tasked to develop curricula by way of designing and developing programmes made up of new courses or modules as well as reviewing and revising existing ones. Pinar (2004) explained that curriculum development is concerned with reviewing, planning, developing, implementing and maintaining the teaching-learning content. Reviewing of curriculum involves identifying what is working well or not at the moment of the review and how it can be maintained or not. Planning involves the development of curriculum materials while developing entails designing, providing the structure of the curriculum intent, content, learning activities, evaluation procedures and field test of curriculum programmes. Implementing is putting the curriculum into practice and ensuring that it effectively meets the intended goals. The process of curriculum development is often not an easy task to someone who does not have principles of curriculum development, theory, change and an understanding of curriculum to engage in a meaningful curriculum development exercise. It was for this reason that Matiru, Mwangi and Schlette (1995, p.2) rightly advanced the view when making reference to university lecturers in Kenya that:

Only a handful of lecturers have been professionally trained in the art of teaching. The assumption has all along been that the possession of a PhD degree was all that an aspiring lecturer needed in order to be able to teach in a university. The rest one imbibed through osmosis.

One would then understand why discussing quality assurance of higher education in Africa in relation to curriculum development is a necessary undertaking at this point. Lack of training for lecturers is not restricted to teaching only but also to an important task underpinning teaching such as curriculum development. Without the requisite knowledge and skills in teaching and curriculum development, it is assumed that university lecturers will not be able to undertake such crucial tasks successfully. Unfortunately, as Maphosa, Mudzielwana and Netshifhefhe (2014) put it that; nothing is imbibed by osmosis but one has to be adequately prepared for curriculum development since the development of curricular requires specific skills and attitudes.

It is important to note from the onset that curriculum planning, which involves the design and development of programmes, is an endeavour for broad-based thinking on teaching, learning and intended learning outcomes before the actual teaching is done. In planning a course or a module, a lecturer has to reflect on how the planned course or module fits into the whole degree programme and its significance thereof. Thijs and Van den Akker (2009) noted that to be effective, curriculum developers require theoretically underpinned and empirically tested curriculum development principles and methods. To this end, curriculum development is not a layman's work but a specialised professional work rooted in deep understanding of what curriculum is. It is for this reason that a clear conceptualization of the definition or meaning of a curriculum is a basic requirement.

\section{A Curriculum as a programme in Higher Education}

Over the past decades, the study of curriculum especially for higher education has received so much attention and in most cases has even become an established component of study in almost all education faculties. Why has that been the case? It is a well-known fact that the graduates of higher education are the future leaders and eventually decision makers in policies that are directing the course of the world. Most of them make the majority middle class of the society as explained by Melber (2016) and thus the skills, values, attitudes and knowledge (competency) that they graduate with in the various institutions that they attend are likely to influence and shape most lives in the society. It is also important to note that education is the basic function that a curriculum saves in any education system and learning institutions. Thus a curriculum embodies the intentions of education; it is the programme of education. A curriculum therefore carries the beliefs, values, attitudes, skills, knowledge and all that education is about. Hence the aspect of quality assurance when it comes to higher education provision starts with how a curriculum is conceptualized and defined by those who have been given the responsibility to develop it. Higher education curriculum developers' understanding of what a curriculum is influences the development of it and hence its quality. Mulenga (2019) explained that it is for this reason that curriculum scholars such as Print (1993) refer to the curriculum as the raison d'etre of education, the very substance of education. Commencing the analysis of the ideas in this paper with such a conceptualization of a curriculum is actually quite appropriate and deliberate because before this 
discourse gets further, it is vital that the concept, curriculum, is understood and appreciated in simple terms from the very beginning. Of course there are various theorizations of curriculum. However that is not the focus of this paper. What then is curriculum development? A clear measure of the quality of a curriculum for higher education is how the process of curriculum development keeps on accommodating itself with the fluidity of societal changes. Mulenga (2019, p. 20) further explained that

If education is brought about as a result of what is implemented from the curriculum and if education is dependent on what the dynamic society needs, then having a curriculum that will stand a test of time is just wishful thinking. By fulfilling the needs of a dynamic society, the conceptualization of a curriculum will continue to slowly accommodate itself with the present educational needs so as to suit the arising needs.

The implication of what Mulenga is explaining here is that quality assurance in higher education curriculum should focus on the process of curriculum development in terms of how flexible it is to changing needs. What is mainly different between curriculum development for primary or secondary school levels and higher education in most African countries is that for the former, curricular is developed centrally while for the later it is developed by the educators of each individual institution, some of whom many have very limited skills and knowledge in curriculum development. However, the challenge in some institutions is that by virtue of being a lecturer it is assumed that one is also able to development a curriculum for the programme that he or she is teaching, which is not necessarily true. And this can be the source of problems when it comes to quality assurance. Prior to engaging in curriculum development, Ornstein and Hunkins (2018) warn that educators must determine whether they are responsible for educating students. Making this distinction is vital for higher education curriculum development and implementation. The fact that one is enrolled in a university programme will not mean that such a one is automatically benefiting from it. Although the general public and even some in education fail to distinguish between the two terms, education and schooling, educators must ascertain to what camp they have allegiance. If this position is not well understood, an institution or a particular programme may be following one of them thinking they are following the other one. Without going into the maze of curriculum models, we can in very few lines try to make a distinction between the two and then conclude about them in relation to quality assurance.

Education and schooling have a troubled relationship, making it necessary for educators especially those in higher education to reflect on just what each concept means. Ever since nations around the world initiated compulsory public school in the $19^{\text {th }}$ century, Ornstein and Hunkins (2018) explained that scholars have queried if schools possessed the capacity to educate. The paradox, however, is that the function of the school is to educate. Education in contrast to schooling enables students to become individuals with intellectual character.

As Ritchhart (2002p. 34) queries that 'why would we be teaching a curriculum if not for intelligence?' schooling tends to indoctrinate while education strives to liberate. Schooling tends to stress efficiency and standardization while on the other hand education endeavours to be messy and spontaneous. With the introduction of Higher Education authorities in most African countries whose mandate is to assure quality, most of these authorities are actually focused more on adherence to standards at the expense of innovation. Schooling attempts to fill students with knowledge while education tries to make students utilize knowledge in thinking and to become intelligent utilizers of information. Thus a curriculum for higher education should be developed and then implemented in such a way that learning result in students actively engaged in rethinking details read or presented and rearranging such data so as to develop insights to which they can claim ownership. To educate so that students are the main actors in their learning requires educators to engage in serious curriculum development.

A curriculum for this century is more than an approved textbook or course outline. Quality assurance of any curriculum for higher education in Africa needs therefore to pay attention to these things in relation to how the curriculum was development and hence being implemented. We however still have lecturers today who are glued and stark with their old notes and expect students to memorise them in the name of preparing such 
students for the known job opportunity. Therefore, one of the biggest challenges for higher education institutions that tend to prepare students for a job, is that the jobs for which students will be prepared for at a particular point during their studies, will not be there at the time they graduate (World Economic Forum, 2017). This is the biggest challenge for higher education curriculum development and eventually the same challenge for quality assurance. What are we advocating for therefore? Are we saying that students should not be awarded degrees or diplomas?

\section{Competencies rather than Degrees and Diplomas}

We have seen that the knowledge debate has shifted from being a philosophical concern focused on concepts of truth and questions about the source and validity of universal knowledge, by way of growing doubts about the adequacy of the conception of human knowledge and its implications to that of applied knowledge and skills which provide real solutions to human challenges. In the recent past with all the knowledge that the world has accumulated in science and technology, we have seen nations taken by surprise and advanced economies brought to a standstill in a very short time. The case in point is the coronavirus outbreak pandemic of 2019 / 2020 which shook the whole world. What are the implications for higher education curriculum and quality assurance? Quality assurance for higher education should focus on competencies acquired by students on the different programmes rather than the document descriptions of degrees and diplomas in curriculum documents. If higher education in Africa wants to remain relevant, its curriculum should be evaluated based on what the industry or labour market wants and what society is predicting to be in future (Rizzo, Kilama and Wuyts, 2015).

Curriculum developers of higher education programmes should therefore note that in a world where technology and climate change are disrupting what we do and how we do it (on an unprecedented level), the labor market is now employing people based on their capabilities or competencies and not only based on degrees or diplomas that they have acquired. And yet what we seem to see is a mind-set of higher education institutions still focusing on mass graduation of students at the expense of competence acquired. Most universities in Africa are struggling to survive financially and therefore, students' numbers are key to raising money through tuition fees (Teferra, 2014). This is a trap that should be avoided because it is likely to compromise the quality of education, if not, the quality of curriculum implementation. Quality assurance should thus focus on the balance that institutions of higher learning are making in terms of numbers of students and the quality of curriculum implementation. It has been noted that Africa has a very young population and thus we expect to see more of this population entering higher education (World Economic Forum, 2017).

Africa's enormous and fast-growing youth demographic is a prize that any developed country would want to win. It provides the entire region with an extraordinary level of human capital that, if realized, is likely to transform African countries and the wider continent for the better, forever. However, this will not come automatically without having quality curriculum in higher education. That is why more and more students, right across the continent, should acquire 21st century skills through higher education: changing how they think and learning how to make it in today's complex global economy. In short, if graduates of higher education in Africa have to make a difference, the curriculum that they go through should teach them to learn how to learn and not simply acquire a degree or diploma. Quality assurance should therefore focus on this aspect. In other words what higher education should strengthen is educating graduates for competencies rather than training them as Mulenga (2020) explained. Therefore, learning how to learn will make such graduates provide sustainable service to society. Here the question of concern is what could be the understanding of a higher education curriculum for sustainable development?

\section{Higher Education Curriculum for Sustainable Development}

At any particular time in the history of the world, scholars and thinkers have never run short of good ideas and futuristic proposals which in essence provide guidelines for educational provision and in particular the curriculum. Today every international and even local forum is referring to Sustainable Development Goals (SDGs) but not long ago we had Millennium Development Goals (MDGs). These international bench marks for development have always been provided at almost free cost. To what extent has higher education curriculum 
development taken advantage of them? Has African higher education lived up to these global and continental expectations? One of the main issues facing the sector is its research and innovation capacity and the ability to use these for the continents transformation (Teferra \& Altbach, 2004). This challenge is a reflection of the curriculum that African scholars in higher education and their students are busy working with. In short, when it comes to quality assurance for higher education curriculum, the quality of it should be measured against such international and global indicators as MDGs and SDGs because at every onetime society expects the application of these international benchmarks in the higher education curriculum. For instance, Dr. Koffi Annan, former United Nations Secretary General, underscored the role of the African universities in the continent's development and in the drive to attain the Millennium Development Goals (MDGs) when he observed that:

The university must become a primary tool for Africa's development in the new century. Universities can help develop African expertise; they can enhance the analysis of African problems; strengthen domestic institutions; serve as a model environment for the practice of good governance, conflict resolution and respect for human rights, and enable African academics to play an active part in the global community of scholars (World Bank, 2000).

Moreover, the African Union Second Decade of Education Action Plan had prioritized higher education as an area for Africa's development, with an emphasis on knowledge generation through centers of excellence, quality assurance, harmonization, regional integration and resource mobilization (Clancy \& Dill, 2009). The same can be said of SDGs today and what is expected from higher education curriculum implementation. For example, the United Nations' Sustainable Development Goal 4 (SDG 4) and the Education 2030 agenda (including Target 4.7), commit countries to ensuring that students acquire knowledge and skills in areas such as sustainable development, human rights, gender equality and global citizenship, innovation and scientific thought among others (USAID, 2014). This already has far reaching consequences on how higher education curriculum should be developed and quality assured. As we have already mentioned in this paper that Africa's demographic dividend provides challenges for policy-makers, in education we can make a significant difference by changing how graduates think as they enter the world of work (Materu, 2007). Young people are Africa's most valuable asset and the single most important key to unlocking sustainable economic growth. The youth bulge is remarkable - its working population is estimated to grow by $70 \%$ by 2035 , reaching 450 million people. Strengthening skills and knowledge so that this enormously valuable asset is fully utilized and millions of young Africans can compete in the global, digitized economy is critical. The region's entire socio-economic future rests on the development of 21st century skills which higher education must provide through its curriculum. However, this should be followed up in quality assurance across higher education institutions through accreditation bodies.

Governments in Africa set for themselves the Agenda 2063, which explains that Africa's human capital is its most precious resource which can only be enriched through sustained investments in education. The Agenda demands that African policymakers invest in skills, science, technology, engineering and mathematics so that the people of Africa can drive the continent's development forward. This is a good and noble focus although as Zulu and Mulenga (2019) puts it, science and mathematics in some parts of the continent are under threat. What this means, however, in terms of higher education curriculum development and implementation, is that African tertiary institutions should not just prepare students for jobs that might be on offer but stimulate them to see the possibilities for innovation and for the creation of their own jobs as Lozano et al (2013) have suggested. Globally, higher education is taking an innovative approach to developing 21st century leaders and this should be the focus and direction for Africa's curriculum development and quality assurance by preparing graduates who will exist in the complex and fast changing future.

\section{$21^{\text {st }}$ Century Higher Education Graduates}

Scholars such as Kouwenhoven (2003), Mulenga and Luangala (2015), Banja and Mulenga (2019) and Mulenga (2015) explained that in developing countries, many higher education institutions experience a growing gap between their curricula and the demands from society, business and industry for a more flexible workforce with high 
competencies. On the other hand, several predictions have been made that the world of work will be significantly different in not long from now. With the advent of artificial intelligence, machines will probably replace the world of human activity. As a way of managing this in terms of higher education planning, current study programs should be redesigned to prioritize the creation of lifelong learners with high level $21^{\text {st }}$ century skills (Association of African Universities, 2009, World Economic Forum, 2017).

Generally speaking, the $21^{\text {st }}$ century skills concept is motivated by the belief that students should acquire the most relevant, useful, in-demand and universally applicable skills which should be prioritized in today's educational institutions. The basic idea is that students, who come of age in the $21^{\text {st }}$ century, need to be taught different skills than those learned by students in the $20^{\text {th }}$ century, and that the skills they learn should reflect the specific demands that will be placed upon them in a complex, competitive, knowledge-based, information-age, technologydriven economy and society. This is important because $20^{\text {th }}$ century university programs have been noticed to be generally structured in consonance with traditional academic departmental and faculty structures (Materu, 2007). Increasingly, however, there are professions and intellectual pursuits that clearly cut across these traditional structures. Universities seldom provided a suitable intellectual and organizational home in which to anchor such programs. It is for this reason that there is a critical need to rethink the way curriculum has been developed over the past years as insinuated by the International Monetary Fund (Abdychev et al, 2018). Quality assurance will help to validate this kind of curriculum development and implementation. Quality assurance should also focus on the extent to which higher education programs are promoting the acquisition of competencies that have been emphasized by many scholars in the framework for the $21^{\text {st }}$ century skills. The framework has three pillars consisting of learning and innovation skills, information, media and technology skills and life and career skills. These can further be broken down as in presented in table 1 ;

Table 1: Framework for $21^{\text {st }}$ Century Skills

\begin{tabular}{lll}
\hline \multicolumn{1}{c}{ Learning and Innovation Skills } & Information, Media and Technology Skills & \multicolumn{1}{c}{ Life and Career Skills } \\
\hline Critical Thinking/ Problem Solving & Information literacy & Flexibility and Adaptability \\
Creativity and Innovation & Media literacy & Initiative and Self-direction \\
& & \\
Communication and Collaboration & Information Communications and & $\begin{array}{l}\text { Social and Cross-cultural skills } \\
\text { Productivity and Accountability } \\
\end{array}$ \\
& Technology (ICT) & Leadership and Responsibility \\
\hline
\end{tabular}

The age of students reproducing lecture notes in tests, tutorial presentations and examinations and lecturers holding on to their notes like sacred scriptures is long gone. Today's societal demands require students who exhibit the competencies indicated in table 1 representing the $21^{\text {st }}$ century framework. Quality assurance for higher education curriculum in Africa should therefore measure the quality and relevance of university and college programs based on this framework. Vogel (2015, p $57)$ begins his chapter three of his book titled Generation Jobless? Turning the Youth Unemployment Crisis into Opportunity, with Richard Riley's famous saying that; "We are currently preparing students for jobs that don't yet exist, using technologies that haven't been invented, in order to solve problems we don't even know are problems yet."
Higher education graduates who will graduate based on how best they can reproduce their lecturers' notes or copy and paste notes from the internet in their assignments have no jobs in this century. Abdychev et al (2018) explained that it is not that jobs will not be there, but jobs will take a different form. It is for this reason that higher education curriculum design has to be ahead of the change.

In their discussion and synthesis study on 21st Century Skills, Voogt and Roblin $(2010,2012)$ draw attention to the range of drivers identified with the increased demand for $21^{\text {st }}$ Century Skills. The reviewed frameworks cited in their study attribute this largely to changes in society, particularly in global terms. Firstly, globalisation and internationalisation are seen as key drivers of change within the economy and labour markets at national, regional and global levels. Today, 
internationalization of higher education is extremely influential in the way the sector is evolving. Secondly, Voogt and Roblin (2010) stated that many commentators also draw attention in particular to the rapid development of technology and its impact on life, work and learning, including in an increasingly globalised context. Most specifically, ICT is seen as driving a shift from an industrialised society towards the information or knowledgedriven society.

Voogt and Roblin (2010) further see these combined factors being regarded as central to the perceived need for and definition of $21^{\text {st }}$ Century Skills at the global level. Higher education curriculum development and quality assurance need to be pitched at a global level because graduates need to function as world citizens. These factors are also reflected in the emerging demands placed upon educational content and delivery as Drap, Rudd, Lopez and Radford (2016) had alluded. Firstly, while industrial societies require factual or procedural models of knowledge, knowledge-based societies place a far greater emphasis on the need for metacognitive knowledge. Secondly, there is evidence of an increased need for individuals to develop capabilities to flexibly adapt to rapidly changing globalised social and economic models. While we make all these recommendations as parameters for quality assurance for higher education in African higher education, we should not forget of the factors that threaten quality at this level. Most of these are internal to the institutions and their respective nations.

\section{Impediments to Curriculum Implementation and Quality Assurance}

Having provided a framework for which to assess curriculum development and quality assurance in higher education in Africa, it is important that we take note of some of the challenges which may impede quality in higher learning institutions. A number of higher education scholars have consistently revealed the same challenges that cut across Africa (Teferra \& Altbach, 2003; Teferra \& Altbach, 2004., Goujon, Haller \& Kmet, 2017; Drap, Rudd, Lopez \& Radford, 2016). The majority of subSaharan African universities share the same challenges which negatively affect quality curriculum implementation. In the early years of post-political independence of most African countries, it was glaringly obvious that the university and higher education in general was regarded as the single most important industry for the production of high-level manpower and the capstone of the entire educational system. It was not surprising then that stakeholders in University education tended to guard jealously the integrity of the university and the quality of graduates produced. It is for this reason that most countries which got independence in the 1960s invested heavily in higher education. As affirmed by Daisi (1997), many graduates from the nation's universities have distinguished themselves in their areas of specialization so much so that some of them are now professors in the best universities across the globe. This attestation is quite resounding in that entrants were developed into quality graduates due to the favourable learning environments that existed. The story however for most universities on the African continent has changed. The strengthening of quality assurance regimes confronts at least the following challenges:

\section{Under funding}

One of the greatest challenges that appear to face most public African universities and other institution of higher learning is that of underfunding (Teferra \& Altbach, 2004). The establishment and the running of tertiary institutions are capital intensive. Running higher learning institutions, therefore, requires significant investment in providing and maintaining a basic level of infrastructure - such as laboratories, modern lecture theatres, up to date libraries, staff salaries, office space, students' accommodation and residential housing. For instance, in a study that was conducted by Mulenga and Chileshe (2020) in some Zambian TEVET institutions, it was revealed that vocational institutions had archaic and out dated workshop equipment which could not be replaced due to lack of financial resources. Cutting edge research is almost non-existent in most universities since it requires a lot of funding. No wonder most private universities on the continent especially just run like secondary schools by concentrating on teaching and mostly providing programmes which do not require expensive infrastructure especially those in the arts.

A number of public Universities in Africa have been supported largely by their governments, but these universities have been grossly under-funded and this has invariably led to the quality being adversely affected. No wonder it is not strange to see some of these institutions characterised by dilapidated and old infrastructure, overcrowded lecture theatres, incessant strikes and student unrest. Due to 
underfunding in research, for instance, African problems which require African solutions through ground breaking research are not there. In medicine and engineering, for instance, vaccines for African diseases and machinery and infrastructural plans and products are spear headed by the west and now the eastern universities.

Mohamedbhai (2011) reports that in most countries, the annual institutional budget allocated by governments is determined by simply adjusting the previous year's budget by a percentage, depending on the availability of funds. In order to fund these institutions properly, what is needed is the use of formula funding which is based on the unit cost per student. This is what can stimulate improvement in institutions and help to achieve more accountability, transparency and eventually lead to quality provision of higher education. What we see however, is that in most public institutions charging of high tuition fees is now the norm if they are to provide quality education. The danger here is that public higher education then is eventually regarded as a private enterprise, receiving decreasing contribution from the state. African governments should therefore recognize that higher education is a "public good" and, accordingly, must benefit from state support (Mohamedbhai, 2011). While fees should be introduced, they should represent only a small proportion of the actual economic cost and should be accompanied by appropriate loan schemes or scholarships for the socially disadvantaged students. In this way, higher education will be available to all classes of youths in Africa (Masaiti, Mwelwa, and Mwale, 2016).

\section{Enrolment Explosion}

With the increase and demand for higher education coupled with the need for financial resources through tuition fees, over enrolment in African universities has become a common feature. Many of the facilities on the ground are being overstretched. For instance, Okebukola (2006) released the list of some overcrowded universities in Nigeria, some of them in excess enrolment of 24,628 students. The story is no different in other public institutions on the continent. This development is surely likely to affect the quality of university education, since excess enrolment usually leads to overcrowded lecture rooms, ineffective teaching and assessment due to pressure of work on the part of the academic staff. Mohamedbhai (2011) explained that the vast majority of public universities in Africa have student enrolment far beyond what they were designed to accommodate. He further explained that enrolment without adequately increasing the infrastructure and other resources can only worsen the situation and affect quality. At the same time, in several African countries, an effort has been taken to rapidly set up new universities that are almost copies of the existing ones. A case in point is in Zambia where four more universities have been established by simply upgrading colleges of education (Masaiti \& Mwale, 2017). This tendency to create new universities by simply upgrading polytechnics and colleges may not help the continent as what Africa needs are differentiated institutions, ranging from research-strong universities to polytechnics and technical colleges, as well as diversified programmes within each institution to cater for different types of learners and needs of the country as Mohamedbhai (2011) suggested.

\section{Poor Management}

The way and manner in which some of the African universities are being managed by the university administrators has also had a consequential effect on quality assurance (Teferra \& Altbach, 2003; 2004). For most of the universities, management means little more than playing the role of "Caretaker." This vital function has been largely reduced to the maintenance of the status quo. Members of university governing councils and other leadership positions in some cases are those who see universities as money-making sources or as methods of pursuing other political or personal interests. Universities in Africa should become aware that quality starts with their commitment to their institution's vision, mission and values and that such a commitment must not be made to serve other political and social ends. Unfortunately, this development significantly negates the concept of a university, particularly in most developing countries of Africa. It seems certain that as long as management continues to play this role, quality assurance will continue to be jeopardized in the universities.

\section{Inadequate staffing and low research output}

One of the reasons for the low level of quality assurance in African universities is a severe shortage of teaching and research staff. The report by the NUC (2006), for instance, shows that only 16,856 out of 72,704 staff in the federal Nigerian universities are academic staff. The situation is no different in one Zambian public university where 
about 1,280 are non-academic staff while about 890 make up the number of academic staff. Many universities in Africa are bottom heavy in terms of academic staff mix. While academic staff members are understaffed against a huge population of students, one would find that non-academic staff members are actually more than the staff that performs the core business of the institutions. For instance, Ntimo-Makara (2003) reported in Lesotho that at the National University of Lesotho there are twice as many non-academic support staff as there are academics. Additionally, Edee (2003) gave the Togo experience which had 1,136 administrative and technical staff in higher education, yet the academic staff numbers are fewer than 730, of whom only 55 percent are full-time. With the numbers of non-academic staff so high, these institutions face several problems, including overstaffing, lack of office space for academic staff, poor communication between the different services and the students, in some cases even delayed salaries as the case has been for some universities in Zambia (Masaiti \& Simuyaba, 2018).

It is also strange to even notice that such nonacademic staff have far much better conditions of service than the academic staff in some institutions and in some cases they make and control the university policies to the detriment of the core business of teaching, research, innovation, industrialization and public service. The scholarship of teaching and learning in higher education especially universities is supported by research which should inform policy and eventually influence development. Lack of research-experienced faculty, brain drain, heavy teaching load, moonlighting by faculty, and lack of resources-such as, library facilities, information and communications technology infrastructure and well-equipped laboratories have greatly affected quality teaching and research in most African universities. The relevance of the research carried out is also another issue that need scrutiny. Most faculty members undertake research for personal gain, with the aim of publishing in internationally refereed journals, which no one can access and just for promotion purposes. The topics often researched on are not even appropriate to national development and staffs do their research as individuals without multidisciplinary dimensions which are essential for solving development problems. Due to lack of state research funding, much of the research is externally funded and being determined by the funders, the topics may not be of direct relevance to national development.

\section{Conclusions and Recommendations}

In conclusion, it is vital to acknowledge that quality assurance for higher education in Africa is no easy task, given the complex conditions of the current millieu of constant change in the technological, economic, social and political spheres of the continent. The following conclusions and recommendations are therefore being made as scholars, researchers and educators in higher education rethink quality assurance in curriculum development and implementation based on the frameworks that the author has put forward in this paper.

\section{Conclusions}

Humanity has entered a new phase in its history with increasingly rapid developments in science and technology. The 21st century is witnessing a rapid acceleration of the development and infusion of new technologies into production processes, everyday life and quality of life projects. At the same time, there is growing global and local complexity in the fabric of societies, so much so that hard-won systems of social organization and cohesion are under the severe threat of breakdown. For African states to benefit in an emancipatory, just and sustainable way, its population must understand and manage the opportunities and the risks. Making this possible should be the fundamental purpose of education and learning in the $21^{\text {st }}$ century. It should above all be the basic task of all African universities since they are the laboratory of ideas for the continent.

As already mentioned there are unstoppable, enormous and profound changes taking place all over the world. Some of these are intensely local and others intensely global, but most are globallylocally interwoven. Higher education and its local and global organizations are ideally placed to play a critical role in addressing these challenges and to develop young people as global and local citizens. This is only possible if curriculum development and quality assurance for the same is done with outmost care, urgency and according to the $21^{\text {st }}$ century developmental landscape. The challenges that threaten higher education curriculum quality assurance are not actually the problem but the mind set of African leaders and citizens is. 


\section{Recommendations}

Two critical recommendations can be made based in this discourse. Firstly, there is a need, to review the nature of educational curricula especially at higher education and find out whether they connect with what is likely to be the world of work in 2030 . Higher education should be a central player in such exercises. Secondly, quality assurance of curriculum development for the African higher education sector should be done through the lens of the $21^{\text {st }}$ century skills and the demands of globally recognized benchmarks such as the sustainable development goals with a focus on the local and international educational needs.

\section{Reference}

Abdychev, A. et al (2018). The Future of Work in Sub-Saharan Africa. Washington DC: International Monetary Fund. African Department.

Association of African Universities. (2009). Abuja Declaration on Sustainable Development in Africa: The Role of Higher Education. Proceedings of the 12th General Conference of AAU, Nigeria.

Banja, K. M. and Mulenga, I. M. (2019). Teacher Education at the University of Zambia and Teacher Quality with Specific Reference to English Language. Makerere Journal of Higher Education, 10 (2), 171-190.

http://dx.doi.org/10.4314/

majohe.v10i2.13.

Clancy, P. and Dill, D.D. (2009). The Research Mission of the University: An Introduction. In Clancy, P. \& Dill, D.D. (Eds.). Vol. 1, Rotterdam: Sense Publishers.

Daisi, K. (1997). Legal, policy and organizational framework for the campaign against examination malpractices and students cults. A paper presented at the National summit on the Legal, policy and organizational framework, International Conference Centre, Abuja. 2-4 December.

Drap, T. A., Rudd, R., Lopez, M. and Radford, D. (2016). Challenges and Solutions to Higher Education Institutions in Africa. International Journal of Education, 8 (1), 4358. http://dx.doi.org/10.5296/ije.v8i1.8742.
Edee, A. B. K. M.(2003).'Togo', in Teferra, D. and Altbach, P. G.(eds.), African HigherEducation: An International Reference Handbook. Bloomington: Indiana University Press, pp. 595-600.

Goujon, A., Haller, M. and Kmet, M. B. (2017). Higher Education in Africa: Challenges for Development, Mobility and Cooperation. London: Cambridge Scholars Publishing.

Kouwenhoven, G.W. (2003). Designing for Competence: towards a Competence-based Curriculum for the Faculty of Education of the Eduardo Mondlane University. Doctoral dissertation. Enschede: Twente University.

Lozano, R., Lukman, R., Lozano, F. J., Huisingh, D., \& Lambrechts, W. (2013). Declarations for sustainability in higher education: becoming better leaders, through addressing the university system. Journal of Cleaner Production, 48, 10-19. http://dx.doi.org/ 10.1016/j.jclepro.2011.10.006

Maphosa, C., Mudzielwana, N. P. and Netshifhefhe, L. (2014). Curriculum Development in South African Higher Education Institutions: Key Considerations. Mediterranean Journal of Social Sciences, 5 (7), 355-366.

Masaiti, G. and Mwale, N. (2017). The University of Zambia: Contextualization and Contribution to Flagship Status in Zambia' in African Flagship Universities in: Role, Impact and Trajectory, Palgrave Macmillan, New York. PP 467-505

Masaiti, G. Mwelwa, K and Mwale, N. (2016). Shifting from Government Bursaries to a Loan Scheme in Higher Education: Exploring Zambian Experience in Student Financial Aid, International Journal of African Higher Education -IJAHE: 2 (2), 5671.

Masaiti, G. and Simuyaba, E . (2018). 'University Education in Zambia: Trends and Current Status' in Education in Zambia at Fifty Years of Independence and Beyond: History, Current Status and Future Prospects, UNZA Press, Lusaka. pp 102-120.

Materu, P. N. (2007). Higher Education Quality Assurance in Sub-Saharan Africa. World 
Bank WorkingPapers. http://dx.doi.org/ 10.1596/978-0-8213-7272-2.

Matiru, B., Mwangi, A., Schlette, R. (Ed) (1995). Teach Your Best: A Handbook for University Lecturers. Bonn: German Foundation for International Development (DSE).

Melber, H. (2016). The Rise of Africa's Middle Class: Myths, Realities and Critical Engagements. London: Zed Books.

Mohamedbhai, G. (2011). Higher Education in Africa: Facing the Challenge in the $21^{\text {st }}$ Century. International Higher Education, $63,1-6$.

Mulenga, I. M. \& Chileshe, E. K. (2020). Appropriateness and Adequacy of Teaching and Learning Resources and Students' Industrial Attachment in Public Colleges of Technical and Vocational Education in Zambia. East African Journal of Education and Social Sciences, 1(2), 30-42. http://doi.org/10.46606/eajess2020v01i02. 0019.

Mulenga, I. M. (2015). English Language Teacher Education Curriculum Designing: A Mixed Methods Analysis of the Programme at the University of Zambia. PhD Thesis. The University of Zambia.

Mulenga, I. M. (2019). Conceptualization and Definition of a Curriculum. Journal of Lexicography and Terminology, 2(2), 1-23.

Mulenga, I. M. (2020). Teacher Education and Teacher Training: Epistemic Practices in Applying both Terms Appropriately. Journal of Lexicography and Terminology, 4 (1), 105-126.

Mulenga, I. M. \& Luangala, J. R. (2015). Curriculum Design in Contemporary Teacher Education: What makes Job Analysis a Vital Preliminary Ingredient? International Journal of Humanities, Social Sciences and Education. 2(1), 39-51.

Ntimo-Makara, M. (2003). 'Lesotho', in Teferra, D. and Altbach, P.G. (eds.), African Higher Education: An International Reference Handbook. Bloomington: Indiana University Press, pp. 372-380.
NUC (2006). 2006 Webomatric Ranking of World Universities: Matters Arising. Monday Memo NUC, Abuja, 5(11), 1-10.

Okebukola, P. A. (2006, July 10). Intensive Retraining Programme for Graduates of Universities for better Quality and Standards. A Keynote Address at the First Oyos State Education Summit, Ibadan.

Ornstein, A. C. and Hunkins, F. P. (2018). Curriculum: Foundations, Principles and Issues. London: Pearson Education Limited.

Pinar, W. F. (2004). What is Curriculum Theory? Mahwah, NJ: Lawrence Erlbaum Associates

Print, M. (1993). Curriculum Development and Design. St. 23 Leondards: Allen and Unwin.

Ritchhart, R. (2002). Intellectual Character. San Francisco: Jossey-Bass.

Rizzo, M., Kilama, B. and Wuyts, M. (2015). The Invisibility of Wage Employment in Statistics on the Informal Economy in Africa: Causes and Consequences. Journal of Development Studies, 51 (2), 149-161.

Teferra, D. (2014). Funding Higher Education in Africa: State, Trends and Perspectives. Councilfor the Development of Social Sciences Research in Africa, 11 (1 \&2), 1951.

Teferra, D. and Altbach, P. G. (2004). African Higher Education: Challenges for the $21^{\text {st }}$ Century. Higher Education, 47, 21-50. doi: 10.1023/B:high.0000009822.49980.30

Teferra, D. and Altbach, P. G. (2003). (Eds). African Higher Education: An International Reference Handbook. Bloomington: Indiana University Press.

Thijs, A., van den Akker, J. (Eds.) (2009). Curriculum in Development. Enschede, Netherlands: SLO-Netherlands Institute for Curriculum Development. Retrieved from http://www.slo.nl/downloads/2009/curricul um-in-development

Vogel, P. (2015). Generation Jobless? Turning the Youth Unemployment Crisis into Opportunity. London: Palgrave Macmillan.

30 East African Journal of Education and Social Sciences (EAJESS) 1(3)20-31 
Voogt, J. and Roblin, N. P. (2010). 21st Century Skills (Discussion Paper). Enschede: University of Twente.

Voogt, J. and Roblin, N. P. (2012). A comparative Analysis of International Frameworks for 21st Century Competences: Implications for National Curriculum Policies. Journal of Curriculum Studies, 44(3), 299321.doi:10.1080/00220272.2012.668938.

USAID. (2014). African higher education: Opportunities for transformative change for sustainable development. Washington, D.C.: APLU.

World Bank Task Force on Higher Education and Society (2000). Higher Education in
Developing Countries: Peril and Promise. Paris: World Bank

World Economic Forum (2017). The Future of Jobs and Skills in Africa: Preparing the Region for the Fourth Industrial Revolution. Geneva: World Economic Forum.

Zulu, J. \& Mulenga, I. M. (2019). Teachers' pedagogical content knowledge, curriculum designing, and Students' comprehension of secondary school ordinary level physics in Lusaka, Zambia. UNESWA Journal of Education, 2 (1), 273288. 